\title{
Propozycja zrównoważonego rozwoju w myśli naukowej Profesora Stefana Kozłowskiego
}

\begin{abstract}
Wstęp
Dnia 17 września 2007 r. w Krynicy, kończąc swój wykład nt. Ograniczenia budownictwa na terenach cennych przyrodniczo w czasie Konferencji Naukowej: Problemy budownictwa na terenach ekologicznie cennych, zorganizowanej przez Komitet Inżynierii Lądowej i Wodnej PAN, KN PZITB oraz Politechnikę Białostocką, zmarł Profesor Stefan Kozłowski ${ }^{1}$. Wpisał się On w moją pamięć jako człowiek wielkiego formatu, z przenikliwym umysłem i czułym sercem, oddany Matce Ziemi i wszystkiemu co na niej istnieje. Był wybitnym pracownikiem naukowym w zakresie geologii surowcowej a następnie ochrony i kształtowania środowiska przyrodniczego. W swoim życiu, w wielowymiarowej działalności naukowej, edukacyjnej, społecznej i politycznej, chciał wszystkich zainteresować estymą środowiska przyrodniczego, w żywiołowo rozwijającej się cywilizacji. Z zamiłowania taternik, z wykształcenia geolog, z profesji ekolog, nauczyciel akademicki, działacz społeczny, poseł na sejm, minister. Szerzyciel idei międzynarodowych rezerwatów biosfery, a na Polskim gruncie także znaczący propagator i kreator idei „zrównoważonego rozwoju”.

W niniejszym artykule, po dość ogólnym przedstawieniu problematyki badawczej Profesora Kozłowskiego, chciałbym skupić się bardziej szczegółowo na ujęciu, rozumieniu i interpretacji idei zrównoważonego rozwoju. Jest to bardzo znacząca część pracy naukowej i dydaktycznej, której poświęcił się Profesor Kozłowski.
\end{abstract} Por. B. Morawska-Nowak, Panie Profesorze Kozłowski, larum graja..., „Co słychać?”
(Informator Polskiego Towarzystwa Tatrzańskiego), 10/2007 (202), s. 2. 


\section{Zwięźle z biogramu naukowego Profesora Stefana Kozłowskiego}

Stefan Kozłowski ${ }^{2}$ urodził się 5 stycznia 1928 roku we Lwowie. W roku 1946 zdał maturę w Krakowie i w tym mieście rozpoczął studia na Akademii Górniczo-Hutniczej na Wydziale Geologiczno-Poszukiwawczym. Po dwóch latach nauki został asystentem Profesora Walerego Goetla w Zakładzie Geologii Ogólnej. Ten czas asystentury, który trwał do roku 1951, odegrał zasadniczą rolę w ukształtowaniu się zainteresowań geologicznych i przyrodniczych. Po studiach został zatrudniony w Biurze Projektów Przemysłu Materiałów Budowlanych, a następnie w Przedsiębiorstwie Geologicznym Surowców Skalnych. Wówczas, w swojej pracy zawodowej i naukowej, skupiał się przede wszystkim na problematyce geologicznej. Szybko uzyskał samodzielność w prowadzeniu prac poszukiwawczych (wiertniczych i szybikowych) oraz w opracowywaniu dokumentacji geologicznej. W sierpniu 1953 roku został przeniesiony służbowo do Przedsiębiorstwa Geologicznego Surowców Skalnych (PGSS) w Krakowie, kierowanego przez inżyniera Adama Kunza. Była to wielka szkoła prowadzenia samodzielnych prac poszukiwawczo-badawczych w różnych formacjach geologicznych, od czwartorzędu aż do prekambru. W PGSS zajmował stanowisko głównego inżyniera dokumentacji, a następnie kierownika działu studiów i projektów.

W roku 1953 powstała pierwsza Jego poważna praca pt.: Intruzje porfirowe w grzbiecie dębnickim. Przy dokumentowaniu złóż porfirowych i melafirowych w Sudetach, Stefan Kozłowski zebrał materiał potrzebny do napisania pracy doktorskiej. Rozprawę doktorską na temat: Pozycja stratygraficzna i tektoniczna wulkanizmu permskiego w centralnej części niecki śródsudeckiej, obronił w 1962 roku na Akademii Górniczo-Hutniczej w Krakowie. W tym samym roku wyjechał do Mongolii w ramach pierwszej polskiej ekspedycji geologicznej kierowanej przez dra Edmunda Rutkowskiego. Po powrocie z Mongolii, Stefan Kozłowski trafia do Warszawy gdzie obejmuje Zakład Złóż Surowców Skalnych w Instytucie Geologicznym (IG). W roku 1966 zostaje powołany na stanowisko samodzielnego pracownika naukowo-badawczego w tymże Instytucie. W między czasie pisze kolejne prace z zakresu badań kimberlitów, fenolitów, andazytów, skaleni oraz kamieni budowlanych i drogowych. W marcu 1969 roku na Akademii Górniczo-Hutniczej w Krakowie otrzymuje stopień doktora habilitowanego, na podstawie pracy pt.: Badania geologiczne nad rozwojem plutonizmu i wulkanizmu na obszarze gór Chasagtu w zachodniej Mongolii.

\footnotetext{
2 Zebrane w tym punkcie artykułu informacje na temat życia i drogi naukowej Stefana Kozłowskiego, będą pochodzić z życiorysu zamieszczonego jako aneks w mojej pracy doktorskiej pt. Filozofia zrównoważonego rozwoju w ujęciu Stefana Kozłowskiego, WFCh UKSW, Warszawa 2002, s. 320-325. Życiorys ten został przygotowany na podstawie dostępnych not biograficznych, a także w oparciu o prywatne rozmowy z Profesorem. Ponadto, posiłkowałem się tutaj artykułem: S, KozŁowski, Moje życie, w: W trosce o Ziemię. Księga ku czci Profesora Stefana Kozłowskiego, Redakcja Wydawnictw KUL, Lublin 2001, s. 11-26 i licznymi informacjami medialnymi, które ukazały się po śmierci Profesora Stefana Kozłowskiego.
} 
Kierując Zakładem Złóż Surowców Skalnych w Instytucie Geologii, Stefan Kozłowski prowadzi dalsze badania nad złożami surowców skalnych południowej Polski, konstruuje tablice litostratygraficzną utworów geologicznych Polski i klasyfikuje surowce mineralne. W latach 1971 - 1982 powstają z Jego udziałem i pod Jego redakcją opracowania baz surowcowych województw: kieleckiego, opolskiego, olsztyńskiego, ziemi lubuskiej i środkowo wschodniej Polski. W tym czasie ukazuje się też biuletyn pt.: $Z$ badań złóż surowców skalnych. Drugim ważnym przedsięwzięciem była praca nad Przegladowa mapa surowców skalnych Polski 1:300 000. Pod redakcją J. Baranowskiego i S. Kozłowskiego w latach 19681970 ukazało się 28 arkuszy tej mapy wraz z obszernym opisem tekstowym. Była to pierwsza mapa surowcowa oparta na kryteriach litologicznych wraz z elementami ochrony przyrody. Mapa ta odegrała istotną rolę w rozwoju strategicznego planowania surowcowo-gospodarczego i przestrzennego. Podsumowaniem wieloletniej pracy nad krajową bazą surowcową stała się monografia Surowce skalne Polski (1975). Drugie uzupełnione wydanie ukazało się w 1986 roku. W roku 1976 Stefan Kozłowski odebrał w Belwederze tytuł profesora nadzwyczajnego nauk przyrodniczych a następnie profesora zwyczajnego, w roku 1983. Zwolniony z funkcji Kierownika Zakładu IG, za opublikowanie sprzeciwu wobec budowy kopalni i huty rud polimetalicznych na Suwalszczyźnie oraz krytycznej oceny wykorzystania zasobów naturalnych w Polsce - kwestie te szczegółowo prezentuje w wydanej książce Przyrodnicze uwarunkowania gospodarki przestrzennej Polski (1983), pracuje dalej w IG, a po jakimś czasie podejmuje także pracę na KUL-u. Przeciwstawia się w różnych swoich publikacjach i wypowiedziach budowie elektrowni atomowej w Żarnowcu czy fabryki tlenku glinu pod Kielcami.

W ten sposób, poczynając od roku 1966 w naukowej twórczości Stefana Kozłowskiego można zauważyć pierwsze przejawy zainteresowania się ochroną zasobów przyrody nieożywionej, projektów rezerwatów i muzeów, ochrony złóż, krajobrazu i środowiska poszczególnych regionów kraju (kieleckiego, łódzkiego, Wyżyny Krakowsko-Wieluńskiej, Bieszczad i innych). We współpracy z Państwową Radą Ochrony Przyrody (PROP) - w której po śmierci Walerego Goetla Profesor Kozłowski prowadził Komisje Ochrony Przyrody - powstaje opracowanie koncepcji „wielkoobszarowego systemu obszarów chronionych”. Po latach, w roku 1998, na podstawie tego projektu z inicjatywy władz regionalnych powołano 109 parków krajobrazowych i wyznaczono 392 obszary chronionego krajobrazu w prawie wszystkich województwach.

W dalszej swojej działalności naukowej, w latach osiemdziesiątych i następnych, Profesor odchodzi od zainteresowań geologicznych, a koncentruje się bardziej na problematyce ochrony i kształtowania środowiska. Z Jego inicjatywy i pod Jego kierunkiem, zostały opublikowane liczne prace i ekspertyzy, które miały na celu wskazać sposób ograniczenia degradacji środowiska przyrodniczego a dalej społeczno-przyrodniczego w Polsce. Tym zagadnieniom poświęcił 
także swoją książkę pt. Gospodarka a środowisko przyrodnicze (1991 r.). Tworzył i starał się realizować różne, często bardzo nowatorskie pomysły proekologiczne. Wcześniej, w czasie obrad Okrągłego Stołu, został przewodniczącym (ze strony „solidarnościowej”) tzw. podstolika ekologicznego. W 1989 roku, został wybrany posłem na Sejm i wiceprzewodniczącym sejmowej Komisji Ochrony Środowiska, Zasobów Naturalnych i Leśnictwa oraz przewodniczącym Komisji Ochrony Środowiska Obywatelskiego Klubu Parlamentarnego. Za jego posłowania Sejm X kadencji uchwalił ustawę o lasach, o Państwowej Inspekcji Ochrony Środowiska, o ochronie przyrody oraz zdążył przyjąć w maju 1991 roku Politykę ekologiczna państwa. Za rządu Jana Olszewskiego (1991-1992) był Ministrem Ochrony Środowiska, Zasobów Naturalnych i Leśnictwa. Działalność Jego ministerstwa podporządkowana została realizacji założeń ekorozwoju kraju. Na konferencji „Środowisko i Rozwój” w Rio de Janeiro w 1992 roku, gdzie podpisał m.in. Konwencję o Ochronie Różnorodności Biologicznej i przyjęto podstawowe dokumenty dotyczące zrównoważonego rozwoju (Deklaracja z Rio i Agenda 21) był szefem polskiej delegacji rządowej. Dnial września 1992 roku został członkiem Rady Ekologicznej przy Prezydencie RP. Profesor Kozłowski pełnił też funkcję przewodniczącego porozumienia "Zielone Płuca Polski” oraz Komitetu „Człowiek i Środowisko” przy Prezydium PAN (nieprzerwanie od 1990 r.). Sprawował jeszcze wiele innych funkcji naukowych, konsultacyjnych i społecznych (m.in. był w Komitecie Inżynierii Środowiska PAN, Komitecie Przestrzennego Zagospodarowania Kraju PAN, w Klubie Ekologicznym, w Radzie Naukowej Zielonych Płuc Polski itp.). Jest autorem, współautorem lub redaktorem kilkunastu książek, dotyczących głównie problemów na styku gospodarki i ochrony środowiska. Jest on również autorem ponad trzystu artykułów i referatów, wygłoszonych na bardzo licznych konferencjach. Dorobek naukowy Profesora Stefana Kozłowskiego, dokumentuje Jego zaangażowanie na rzecz ochrony i kształtowania środowiska przyrodniczego. W ostatnich latach, Profesor propagował ideę ochrony georóżnorodności uznając, że powinna ona być treścią międzynarodowej konwencji odpowiadającej Konwencji o różnorodności biologicznej.

Bardzo ważną częścią pracy, zaangażowania i dorobku naukowego Profesora Stefana Kozłowskiego, było kreowanie i wdrażanie w życie koncepcji zrównoważonego rozwoju. Z ważnych książek i opracowań odnoszących się do zrównoważonego rozwoju można wymienić: Ochrona krajobrazu (1980), Problemy ochrony $i$ kształtowania środowiska przyrodniczego $w$ planowaniu przestrzennym - red. (1986), Rio - początek ery ekologicznej (1993), Ekorozwój w gminie - materiały informacyjne do przygotowania programu ekorozwoju gminy (1993), Droga do ekorozwoju (1994), Przyrodnicze kryteria gospodarki przestrzennej kraju, województwa i gminy (1996), W drodze do ekorozwoju (1997), Ekologiczne problemy przyszłości świata i Polski. Komitet prognoz „Polska w XXI wieku” przy prezydium PAN (1998), Ochrona litosfery - red. (1998), Ekorozwój gminy Józefów (1999), Ekorozwój gminy 
Strzyżewice (1999), Wokół mnożnika cztery - red. (2000), Ekorozwój. Wyzwanie XXI wieku (2000), Ochrona środowiska. Unia Europejska - Polska (2003), Regionalna strategia rozwoju zrównoważonego - red. (2004), Przyszłość ekorozwoju (2005), książka wydana pośmiertnie: Zrównoważony rozwój - program na jutro (2008) i wiele innych. Oprócz książek, temu zagadnieniu poświęcił mnóstwo artykułów, ekspertyz, komentarzy i referatów wygłoszonych na wielu konferencjach naukowych. Nie sposób w tym miejscu wymienić wszystkich tytułów tych publikacji i wystąpień. Przechodzę więc w następnej części tego artykułu, do ogólnego przedstawienia Jego tez, konstrukcji i propozycji związanych z ideą „zrównoważonego rozwoju” i skutecznym sposobem jej wdrażania w życie.

\section{Zrównoważony rozwój w rozumieniu Stefana Kozłowskiego}

Rozwój cywilizacyjny, kreowany przez współczesną społeczność światową staje się trudny do utrzymania w dłuższej perspektywie czasowej bez ryzyka katastrofy socjalnej, ekonomicznej i ekologicznej na skalę całej planety. Zmiany w przyrodzie spowodowane jej degradacją, zaczęły przybierać coraz większe rozmiary i zaczęły niepokoić współczesne społeczeństwa. Długoterminowe prognozy dynamiki zjawisk degradotwórczych wskazują na nasilające się konflikty o tak dużej skali, że mogą one nie tylko zahamować rozwój cywilizacyjny, ale wręcz zagrozić dalszej egzystencji człowieka na ziemi ${ }^{3}$. W to stwierdzenie wpisuje się myśl Profesora Stefana Kozłowskiego, który uważa, i tak m.in. napisał w swojej książce Przyszłość ekorozwoju, że upadek wielu poprzedzających nas kultur miał zawsze swe podłoże w ignorowaniu praw przyrody ${ }^{4}$. Jest to punkt wyjścia dla przyjęcia i dalszego rozwijania koncepcji zrównoważonego rozwoju, jako alternatywy, wyzwania i przyszłości dalszego rozwoju cywilizacyjnego.

Idea zrównoważonego rozwoju czy ekorozwoju ${ }^{5}$, w myśli naukowej Profesora Stefana Kozłowskiego, pojawiła się dużo wcześniej niż jej światowa akceptacja,

3 Por. A. King, B. SchneIder, Pierwsza rewolucja globalna. Jak przetrwać? Raport Rady Klubu Rzymskiego, Warszawa 1992; D. H. Meadows, D. L. Meadows, J. Randers, W. W. Behens, Granice wzrostu, Warszawa 1993; D. H. Meadows; D. L. Meadows, J. Randers, Przekraczanie granic. Globalne załamanie czy bezpieczna przyszłość? Warszawa 1995.

Por. S. KozŁowski, Przyszłość ekorozwoju, wyd. KUL, Lublin 2005, s. 27-34.

5 Ang. termin sustainable development $\mathrm{w}$ języku polskim przetłumaczony został na różne sposoby o wielu znaczeniach. Używane są w literaturze fachowej takie pojęcia jak: rozwój zrównoważony, trwały rozwój, samopodtrzymujący się rozwój bądź po prostu ekorozwój. Ta ostatnia translacja uwypukla w sposób szczególny w dalszym rozwoju cywilizacyjnym znaczenie przyrody i zachowanie praw ekologii. Profesor Kozłowski w pierwszym etapie swoich fascynacji sustainable development, posługiwał się częściej wyrazem ekorozwój. Później, zwłaszcza od roku 1997 kiedy to zasada zrównoważonego rozwoju została wpisana do Konstytucji RP, przeszedł na nomenklaturę zrównoważony rozwój. W ogólnym jednak rozumieniu możemy przyjąć, 
która nastąpiła na Szczycie Ziemi w Rio de Janeiro ${ }^{6}$. Jeszcze przed Światową Konferencją „Środowisko i Rozwój” w Brazylii, w 1985 roku Profesor Kozłowski zaproponował i opublikował swoją pierwszą koncepcję ekorozwojuㄱ. Przedstawił w niej cele, zasady i prawa ekorozwoju, a także propozycje ich realizacji. Generalnie wtedy Stefana Kozłowski za ekorozwój uznał „....te wszelkie działania, które poprawiając warunki życia człowieka na Ziemi, nie powodują degradacji środowiska przyrodniczego" ${ }^{3}$. Rozwijając dalej swoją myśl, przypisuje on zrównoważonemu rozwojowi ,...nadrzędność wymogów ekologicznych, których nie należy zakłócać przez wzrost cywilizacji oraz rozwój kulturalny i gospodarczy”, a gospodarka kraju akceptującego zasady zrównoważonego rozwoju opiera się na zasadzie poszanowania zasobów przyrody ${ }^{10}$. Koncepcja ekorozwoju ,...polega na takim gospodarowaniu zasobami przyrody, aby nie tylko nie doprowadzić do ich degradacji, ale przyczynić się do ich rozwoju i ulepszenia"11. Według Kozłowskiego, rozwój zrównoważony powinien opierać się na „...technologiach i procesach nie powodujących kryzysu niedoboru oraz zanieczyszczenia i degradacji środowiska życia człowieka"12. Chodzi więc o stosowanie w procesach zrównoważonego rozwoju technologii miękkich i zamkniętych cykli ekologicznych oraz stosowania takich działan, które prowadziłyby do podtrzymania i kondycji psychicznej człowieka ${ }^{13}$.

Powtarzając za Deklaracja ekorozwoju przyjętą na konferencji w Białowieży w roku 1990, Stefan Kozłowski stwierdza, że „ekorozwój jest programem restruktury-

że terminów tych nasz Autor używał zamiennie, mając na myśli ten sam przedmiot materialny i formalny. Również i w tym artykule te terminy będą używane zamiennie, z właściwa sobie interpretacją, jeśli zajdzie taka potrzeba.

6 Szerzej o samej idei zrównoważonego rozwoju, znaczeniu, celach, zasadach i wieloznaczności tego pojęcia, pisałem m.in. w takich artykułach jak: A. Sкоwrońsкi, Pojęcie i cele ekorozwoju, w: Ochrona środowiska społeczno-przyrodniczego w filozofii i teologii, praca zbior. pod red. J. M. Dołęgi, J. W. Czartoszewskiego i A. Skowrońskiego, Wyd. UKSW, Warszawa 2001, s. 488-500; tenże, Uwarunkowania, założenia i realizacja zrównoważonego rozwoju, „Sozologia” nr 1/2003, s. 73-81; tenże, Idea zrównoważonego rozwoju w polskiej polityce ekologicznej, „Studia Ecologiae et Bioethicae” nr 1(2003), s. 653-681; tenże Wieloznaczność koncepcji zrównoważonego rozwoju, „Sozologia” nr 2/2003, s. 61-70; tenże, Zrównoważony rozwój perspektywą dalszego postępu cywilizacyjnego, „Problemy Ekorozwoju”, vol. 1, nr 2(2006), s. 33-46; tenże, Zrównoważony rozwój perspektywa dalszego postępu cywilizacyjnego, „Problemy Ekorozwoju”, vol. 1, nr 2(2006), s. 33-46; tenże, A Civilization Based on Sustainable Development: Its Limits and Prospects, „Sustainable Development” vol. 16, nr 2(2008), s. 117-125.

7 Koncepcja ta została opublikowana w: S. KozŁowski, Ekorozwój. Koncepcja ekorozwoju, „Człowiek a Światopogląd” 1985, nr 5, s. 37-58.

Tamże, s. 46

9 S. KozŁowski, Droga do ekorozwoju, PWN, Warszawa 1994, s. 24.

10 S. KozŁowski, Ekologiczny wariant rozwoju kraju, „Nauka Polska”, 1988, nr 5, s. 177.

11 S. KozŁowsкi, Koncepcja ekorozwoju w warunkach polskich, „Nauka Polska” 1989, nr 6(247), s. 63.

12 S. KozŁowski, Ekologiczne problemy przyszłości świata i Polski, Komitet Prognoz „Polska w XXI wieku" przy Prezydium PAN, Dom Wyd. ELIPSA, Warszawa 1998, s. 69.

13 Tamże. 
zacji powiązań ekonomicznych, społecznych i technicznych, mającej na celu ochronę przyrody i środowiska człowieka na użytek obecnego i przyszłych pokoleń oraz uznania wartości przyrody jako takiej"'14. Zgadzając się z dalszą treścią Deklaracji, nasz Autor orzeka, że ekorozwój obejmuje:

- długotrwałe wykorzystanie odnawialnych zasobów naturalnych,

- efektywną eksploatację nieodnawialnych źródeł energii,

- utrzymanie stabilności procesów ekologicznych i ekosystemów,

- ochronę różnorodności genetycznej oraz ogólną ochronę przyrody,

- zachowanie i polepszenie stanu zdrowia ludzi, bezpieczeństwa pracy i dobrobytu ${ }^{15}$. Ekorozwój jest więc szansą i dla zniszczonych ekosystemów przyrodniczych i dla polskiej gospodarki. Trzeba pamiętać, że odtwarzanie i wymiana zagrożonych ekosystemów wymaga niewspółmiernie większych nakładów finansowych, niż gospodarowanie na zasadach zrównoważonego rozwoju. Zatem gospodarowanie ekosystemami w sposób nie naruszający ich równowagi to najbardziej efektywny i najtańszy sposób gospodarowania ${ }^{16}$. Taka koncepcja gospodarowania jest uzasadniona i konieczna do realizacji, ale zakłada ona reorientację dotychczasowych strategii rozwojowych $\mathrm{kraju}^{17} \mathrm{i}$ przeniesienie decyzji gospodarczych na poziomy lokalne ${ }^{18}$.

Innymi słowy, nasz Autor, koncepcję zrównoważonego rozwoju przedstawia, jako takie gospodarowanie środowiskiem, które zapewnia rozwój gospodarczy bez niszczenia walorów i zasobów przyrody” ${ }^{19}$. Dotyczy „konieczność dostosowania modelu gospodarczego do naturalnych uwarunkowań przyrodniczych" ${ }^{20}$ ponieważ „....najtańsze i najbardziej efektywne jest takie gospodarowanie zasobami przyrody, które nie doprowadza do jej degradacji czyli przekroczenia naturalnych barier środowiskowych"21. Chodzi wiec o zespolenie wszystkich działań w taki sposób aby poprawić życia człowieka na ziemi, nie naruszając i nie degradując zbytnio środowiska przyrodniczego ${ }^{22}$. To rozumienie zrównoważonego rozwoju, mieści się w nurcie

14 S. KozŁowski, Ekorozwój. Wyzwanie XXI wieku, Wyd. Naukowe PWN, Warszawa 2000, s. 252.

15 Tamże; tenże, Rio - początek ery ekologicznej. Szczyt Ziemi, Biblioteka Ery Ekologicznej. Towarzystwo Przyjaciół Filozofii Ekologicznej, Wyd. AKAPIT PRESS, Łódź 1993, s. 143.

16 Por. S. KozŁowski, Koncepcja ekorozwoju w Polsce, w: Ekorozwój szansa przetrwania cywilizacji. Materialy z Konferencji Polskiego Klubu Ekologicznego, Prace Naukowe Okregu Małopolska, t. III, Wyd. AGH, Kraków 1986, s. 114.

17 Por. S. KozŁowski, Zrównoważony rozwój - wyzwanie przyszłości, „Człowiek i Przyroda”, 1996, nr 5, s. 22 i nst; tenże, Droga do ekorozwoju...., dz. cyt., s. 56.

18 Por. S. KozŁowski, Ekorozwój w gminie. Materiały informacyjne do przygotowania programu ekorozwoju gminy, Wyd. Ekonomia i Środowisko, Białystok - Kraków 1993, s. 18.

19 Tamże.

20 S. KozŁowsKi, Ekorozwój. Koncepcja ekorozwoju..., art. cyt., s. 56.

21 S. KozŁowski, Koncepcja ekorozwoju w warunkach polskich..., art. cyt., s. 63; por tenże, Bariery życia, „Problemy”, 1983, nr 4.

22 Por. S. KozŁowski, Koncepcja ekorozwoju w Polsce, w: Ekorozwój szansa przetrwania cywilizacji..., dz. cyt., s. 106 
ustaleń UNEP, opracowań przygotowanych dla Klubu Rzymskiego, raportu Pani G. H. Brundtland, Światowej strategii ochrony przyrody i Światowej karty ochrony przyrody oraz innych dokumentów wypracowanych pod egidą ONZ. Nawiązuje także do społecznej myśli Kościoła katolickiego.

Oprócz tych ustaleń i dokumentów, do konstrukcji swojej wizji zrównoważonego rozwoju, Stefan Kozłowski wykorzystuje także założenia ery ekologicznej ${ }^{23}$. Nowy ład społeczno-gospodarczy (zrównoważony rozwój) można w opinii Kozłowskiego wprowadzić skutecznie w życie, jedynie na bazie założeń ery ekologicznej. Opierając się na dokumentach z Rio i na publikacji przygotowanej dla Klubu Rzymskiego (Beyond the Limits) ${ }^{24}$, nasz Autor wymienia dwanaście podstawowych założeń ery ekologicznej. Są to ${ }^{25}$ :

- uznanie rozwoju psychicznego człowieka za główny cel życia,

- określenie nieprzekraczalnego poziomu zaspokajania własnych potrzeb materialnych,

- przyjęcie przeciętnej dzietności w rodzinie na dwoje dzieci,

- zaakceptowanie koncepcji zrównoważonego rozwoju (ekorozwoju),

- dążenie do ochrony głównych ekosystemów Ziemi,

- opanowanie wiedzy o zarządzaniu zasobami przyrody,

- przyjęcie koncepcji wspierającego, otwartego systemu ekonomicznego,

- przyjęcie zasady sprawiedliwego handlu,

- opodatkowanie krajów uprzemysłowionych na rzecz państw rozwijających się,

- kreowanie narodowych polityk ekologicznych,

- rozwijanie praw i aktywności obywateli,

- tworzenie nowych proekologicznych struktur organizacyjnych.

Era ekologiczna „ma być okresem światowego partnerstwa ukierunkowanego na zrównoważony rozwój wszystkich państw"26. Realizując założenia tejże ery, światowa społeczność będzie zdolna osiągnąć wyższą jakość życia. Wypełnienie po-

${ }^{23}$ Zrównoważony rozwój ma być podstawą realizacji założeń ery ekologicznej. Era ekologiczna ma zastąpić dotychczasową erę przemysłową. Era ekologiczna polega na całkowicie zmienionym podejściu do Ziemi, jako naszego „domu” w którym bytujemy. Era ekologiczna uwzględnia współzależności naszego życia z rytmem planety zgodnym z prawami funkcjonowania wszechświata. W erze ekologicznej konieczna jest też zmiana dotychczasowej mentalności człowieka. Człowiek ery ekologicznej musi cechować się wrażliwością ekologiczną, świadomością ekologiczną i musi posługiwać się rozumem ekologicznym. Powstaje w ten sposób pojęcie człowieka ekologicznego. Założeniom ery ekologicznej wiele uwagi i miejsca poświęca w swojej twórczości nasz autor. Patrz m.in.: S. KozŁowsKi, Rio - początek ery ekologicznej..., dz. cyt., s. 138-143; tenże, Droga do ekorozwoju..., dz. cyt., s. 83 i nst.; tenże, Ekorozwój wyzwanie XXI wieku..., dz. cyt, s. 80 i nst.

24 Por. D. H. Meadows, D. L. Meadows, J. Randers, Przekroczenie granic..., dz. cyt.

25 S. KozŁowski, Rio - początek ery ekologicznej..., dz. cyt., s. 140; tenże, Droga do ekorozwoju..., dz. cyt., s. 84; por. tenże, Ekorozwój wyzwanie XXI wieku..., dz. cyt., s 81-91.

26 S. KozŁowski, Ekologiczne problemy przyszłości świata..., dz. cyt., s. 39. 
stulatów ery ekologicznej, stanowi konieczny warunek, by wprowadzić nowy ład społeczno-gospodarczy oparty na zasadach zrównoważonego rozwoju.

Oficjalne założenia filozoficzne i gospodarcze zrównoważonego rozwoju zostały sformułowane $\mathrm{w}$ drodze uzgodnień i przyjęte $\mathrm{w}$ Brazylii w czasie trwania konferencji „Środowisko i Rozwój”. Minister Stefan Kozłowski, wówczas przewodniczący polskiej delegacji na Szczyt Ziemi w Rio de Janeiro, prezentował tam polskie stanowisko. Dlatego w dalszej swojej myśli i pracy wokół koncepcji zrównoważonego rozwoju i jej dostosowywania do warunków polskich, Profesor Kozłowski odnosi się w sposób bezpośredni i pośredni do końcowych ustaleń tejże konferencji, zamieszczonych m.in. w Deklaracji z Rio czy Agendzie 21. Syntezując swoje wcześniejsze przemyślenia ustala, że ekorozwój (ecodevelopment) oznacza rozwój oparty na kryteriach przyrodniczych a zrównoważony rozwój (sustainable development), to rozwój rozumiany integralnie $\mathrm{w}$ znaczeniu ekologicznym, ekonomicznym i społecznym. Jest to zatem ujęcie szersze i nadrzędne w stosunku do ekorozwoju ${ }^{27}$. Te ustalenia stanowią dla naszego Autora podstawa wyjściowa dla dalszych dywagacji, dopracowywania i dostosowywania do polskich realiów ogólnoświatowej idei zrównoważonego rozwoju.

W swoich analizach Profesor Kozłowski zwraca uwagę na trzy istotne cechy zrównoważonego rozwoju (ekorozwoju). Pierwsza z nich dotyczy utrzymania równowagi w środowisku przyrodniczym i technicznym, a także równowagi duchowej człowieka. Stan równowagi ma także zapewnić pomyślność ekonomiczną i ochronić przed gwałtownymi załamaniami i kryzysami gospodarczymi. Zrównoważony rozwój oznacza także równowagę międzypokoleniową, międzyludzką i międzyregionalną polegającą na ciągłym sprawiedliwym rozwoju obejmującym wszystkich ludzi ${ }^{28}$. Druga cecha odnosi się do trwałości (stabilności) procesów rozwojowych. Trwałość (stabilność) rozwoju ma wyeliminować różnego rodzaju sytuacje kryzysowe rodzące się w działalności gospodarczej i społecznym funkcjonowaniu ludzi. Trwałość jest gwarantem ciągłego i niezachwianego rozwoju naszej cywilizacji ${ }^{29}$. Wreszcie trzecia cecha zrównoważonego rozwoju to samopodtrzymywanie się. Rozwój charakteryzujący się samopodtrzymywaniem (sustain), zabezpiecza i utrzymuje przede wszystkim aktualny stan rozwoju. Po utrwaleniu tego etapu jest możliwe prognozowanie dalszego rozwoju ${ }^{30}$.

Według Niego głównym celem sustainable development jest „poszukiwanie środków i warunków zabezpieczających długotrwałe zachowanie funkcji systemu ekologicznego związanych ze światem organicznym"31. Ogólnym celem zrównoważonego rozwoju - w myśl koncepcji Kozłowskiego - jest zaspokojenie fizycznych i psychicz-

\footnotetext{
27 Por. S. KozŁowski, Przyszłość ekorozwoju..., dz. cyt., s. 49.

28 Por. S. KozŁowski, Ekologiczny problem przyszłości..., dz. cyt., s. 68.

29 Por. tamże.

Por. tamże, s. 69; tenże, Przyszłość ekorozwoju..., dz. cyt., s. 49.

S. KozŁowski, Zrównoważony rozwój - wyzwanie przyszłości..., art. cyt., s. 13.
} 
nych potrzeb człowieka przez prawidłowe ułożenie jego stosunków do środowiska przyrodniczego. Dla realizacji tego celu, nasz Autor proponuje wprowadzenie w środowisko życia człowieka ładu gospodarczego, funkcjonalnego i estetycznego ${ }^{32}$. W skali globalnej, oprócz nowych technologii potrzebny jest także nowy styl życia. Przyszłość strategii zrównoważonego rozwoju opiera się na przyjęciu wielu kryteriów - zasad, które pomogą go wdrożyć w życie. Do tych zasad zalicza: kompatybilność, możliwość wprowadzenia do praktyki, zdolność do włączenia, odwracalność, elastyczność, efektywność, wydajność, ograniczoność i zgodnosśćs ${ }^{33}$. Dopiero zintegrowanie tych wszystkich wymogów „,brzegowych”, pozwoli zrealizować szczegółowe cele zrównoważonego rozwoju, wśród których Profesor Kozłowski wymienia:

- utrzymanie bezpiecznego dla życia i zdrowia środowiska,

- zabezpieczenie równowagi ekologicznej w podstawowych ekosystemach,

- przywrócenie i utrwalenie warunków niezbędnych dla odnowy sił człowieka,

- możliwość dalszego rozwoju gospodarczego ${ }^{34}$.

Wszystkie te cele muszą być zdaniem Kozłowskiego podporządkowane zasadom etyki ${ }^{35}$. Gwarantem realizacji i skuteczności tych celów, jest zdaniem naszego Autora przyjęcie ascezy ekologicznej ${ }^{36}$. Realizacja wszystkich tych słusznych celów koncepcji zrównoważonego rozwoju w oparciu o długoterminowe i konkretne strategie wdrożeniowe, w opinii Profesora Kozłowskiego, powinna przynieść społeczności światowej korzyści zarówno w wymiarze społecznym, środowiskowym jak i ekonomicznym.

W nawiązaniu do polskich uwarunkowań - szczególnie przemian ustrojowych i strukturalnych, których pokłosia ciągle doświadczamy - zrównoważony rozwój to „proces zakładający restrukturyzację stosunków gospodarczych, społecznych i technicznych w celu zachowania środowiska naturalnego i otoczenia człowieka dla obecnej i przyszłej generacji. Uznając, że przyroda jest wartością samą w sobie, następować powinno kojarzenie potrzeb i aspiracji społeczeństwa i państwa z możliwościami jakie daje środowisko, którym dysponujemy ${ }^{37}$. Każdy kraj - w tym także Polska - powinien rozwijać gospodarkę dostosowaną do naturalnych uwarunkowań przyrodniczych. Przyjmując kryteria ekorozwoju, nasz kraj może zgodnie z zasadami naturalnego funkcjonowania ekosystemów, wykorzystać efektywnie zasoby i walory swego środowiska przyrodniczego ${ }^{38}$. W opinii Kozłowskiego ,....koncepcja

32 Myśl taką przejmuje za: B. Zaufal, Problematyka i założenia ekorozwoju, w: Ekorozwój szansa przetrwania cywilizacji.., dz. cyt. Por. S. KozŁowsкi, Droga do ekorozwoju..., dz. cyt., s. 57.

33 Szerzej zob.: Przyszłość ekorozwoju..., dz. cyt., s. 55-56.

34 Por. np.: S. KozŁowski, Ocena gospodarki zasobami naturalnymi, Biul. KPZK, z. 123, Warszawa 1983.

35 Por. S. KozŁowski, Koncepcja ekorozwoju w warunkach Polskich, art. cyt., s. 62; tenże, Przyszłoś ekorozwoju..., dz. cyt., s. 50-51.

36 Por. S. KozŁowski, Ekorozwój. Wyzwanie XXI wieku..., dz. cyt., s. 108; tenże, W drodze do ekorozwoju..., dz. cyt., s. 133.

37 S. KozŁowski, Polityka ekologiczna państwa, „Środowisko i Rozwój” nr 1 (1992), s. 5.

38 Por. S. KozŁowski, Droga do ekorozwoju..., dz. cyt., s. 57. 
ekorozwoju ma wszelkie szansę powodzenia w naszych warunkach klimatycznych, glebowych, wodnych i posiadanych surowców mineralnych"39. Trzeba tylko tak pokierować rozwojem, aby nie doprowadzić do destrukcji zasobów przyrodniczych.

Podejmując się pewnych uogólnień wynikających $\mathrm{z}$ analizy poszczególnych prace Stefana Kozłowskiego na temat zrównoważonego rozwoju, można stwierdzić, że dla Niego ta koncepcja i alternatywa rozwojowa, to przede wszystkim ład zintegrowany. Rzeczywista bowiem współzależność podstawowych sfer rozwoju oznacza, że ład zintegrowany musi być kształtowany jako ład ekologiczny, ład społeczny, ład ekonomiczny, ład przestrzenny i instytucjonalno-polityczny z uwzględnieniem obiektywnych praw rozwoju społecznego, ekonomicznego i przestrzennego zagospodarowania oraz naturalnych praw ładu ekologicznego. Kozłowski niezwykle dużą wagą przykłada do rozwoju całego człowieka i dlatego ważny jest dla Niego postulat, uznający rozwój psychiczny człowieka za główny cel życia.

\section{Zakończenie}

Obok krótkiego życiorysu naukowego, zostały tu przedstawione wybrane określenia i definicje oraz bardzo ogólnie ujęte uwarunkowania, założenia i cele zrównoważonego rozwoju, które w swojej pracy naukowej zaproponował Stefan Kozłowski. Realizacja tych celów i zasad może prowadzić do rozkwitu gospodarczego, społecznego i to wszystko z poszanowaniem natury i innych elementów środowiska. Taka jest główna myśl Profesora Kozłowskiego, który zabiegając o ochronę środowiska przyrodniczego dostrzegała również potrzebę poprawy jakości życia i dobrobytu na Ziemi obecnych i przyszłych pokoleń.

Szczegółowej analizie można poddać wiele konkretnych stwierdzeń i propozycji składających się na systemowe i w miarę metodologiczne ujęcie kwestii sustainable development. Wystarczy tu tylko wspomnieć chociażby o trójczłonie składającym się w obrazie Profesora na całość zrównoważoną, czy o konkretnym przełożeniu ogólnej zasady „myśl globalnie a działaj lokalnie”. Zajmując się zrównoważonym rozwojem dotykamy wszystkich sfer naszego istnienia, zarówno tych materialnych jak i duchowych. Właśnie ten psychiczny i duchowy aspekt, był ciągle uwypuklany w publikacjach naszego Autora i w zasadzie to on stanowi o specyficznym ujęciu tej koncepcji. Te i inne propozycje, jestem przekonany, że doczekają się prędzej czy później swego opracowania a może i rozwinięcia czy też potrzebnego jeszcze udoskonalenia. Bez wątpienia kreatywna myśl naszego Autora, zasługuje na uznanie, uwagę ale i dalszą kontynuację dla dobra przyrody, obecnych i przyszłych pokoleń. Z takim przesłaniem i zadaniem, pozostawił nas Profesor Stefan Kozłowski.

\footnotetext{
39 S. KozŁowski, Koncepcja ekorozwoju w Polsce, w: Ekorozwój szansą przerwania cywilizacji..., dz.
} cyt., s. 105. 


\title{
The proposal of the sustainable development inwards of scientific works of Professor Stephen Kozłowski
}

\author{
SUMMARY
}

The article is connected with the life and scientific works of Professor Stephen Kozlowski died in September 2007. He was a great research scientist working with the geology of raw materials and then with the conservation and formation of natural environment. Last 25 years of his scientific work he was engaged in the creation of the concept of sustainable development and in the promotion of the concept in Polish social, economic and political life. Using the term "sustainable development" he meant all the activities which improve man's life conditions and which do not cause the degradation of natural environment. Such effect can be obtained by equalizing of three development vectors: natural, economic and cultural. He proposed that Poland should adapt the economic progress to natural conditions of environment. He said that the idea of the sustainable development being based on the foundations of ecological era had all chances to make a success in our conditions of weather, soil, water and raw minerals. 